Proceedings

\title{
The Twisted-Wing Insects (Strepsiptera) of South-Eastern Belarus $^{\dagger}$
}

\section{Artsiom Ostrovsky}

Citation: Ostrovsky, A. The

Twisted-Wing Insects (Strepsiptera) of South-Eastern Belarus, in Proceedings of the 1st International Electronic Conference on Entomology, 1-15 July 2021, MDPI: Basel, Switzerland, doi:10.3390/IECE-10518

Published: 1 July 2021

Publisher's Note: MDPI stays neutral with regard to jurisdictional claims in published maps and institutional affiliations.

Copyright: (C) 2021 by the authors. Submitted for possible open access publication under the terms and conditions of the Creative Commons Attribution (CC BY) license (http://creativecommons.org/licenses /by/4.0/).
Department of Public Health and Health Care with the course of the Faculty of Professional Development and Retraining, Gomel State Medical University, Lange Str. 5, 246000 Gomel, Belarus; Arti301989@mail.ru Correspondence: Arti301989@mail.ru

+ Presented at the 1st International Electronic Conference on Entomology (IECE), 1-15 July 2021; Available online: https://iece.sciforum.net/.

Abstract: An overview of the twisted-wing insects for the South-Eastern Belarus is provided. Our own researches (2016-2021) of species compositions of the twisted-wing insects in South-Eastern Belarus were executed in different biotopes on the territory of Gomel area. Five species from two families - Hylecthrus rubi Saunders, 1850, Stylops hammella Perkins, 1918, S. melittae Kirby, 1802, S. thwaitesi Perkins, 1918 and Paraxenos sphecidarum (Dufour, 1837) - have been recorded. Collection data for each species are presented and their known distribution and biology briefly discussed.

Keywords: faunistics; hosts; twisted-wing insects; Strepsiptera; South-Eastern Belarus

\section{Introduction}

Members of the order Strepsiptera display highly peculiar morphology and lifestyles. They are small to medium sized insects (1.0-7.5 mm long) exhibiting extreme sexual dimorphism [1,2]. Free living and flying males have twisted hind wings, while their fore wings are reduced to clublike appendages. Usually endoparasitic and wingless females are known to colonize members of seven insect orders [2,3]. Approximately 600 Strepsiptera species are known to exist globally [4,5], while 30 species from 7 families are known in Europe [6,7].

The order Strepsiptera in Belarus hasn't been studied, data on the record of one species Stenocranophilus anomalocerus Pierce, 1918 from the family Halictophagidae, parasitoid of Liburnia Stel, 1866 (Hemiptera: Delphacidae), has been published previously [8]. Continuing the research, 3 more species of twisted-wing insects have been found in Belarus [9-11]. The present study aims to summarize and contribute new data to the already published results.

\section{Materials and Methods}

The materials were obtained by the author using standard collection methods on the territory of Gomel (the main research), Bragin and Loev districts of Gomel area during the field seasons of 2016-2021. An analysis of these collections made it possible to provide new faunistic information about 5 species of twisted-wing insects. The asterisk marks the species first discovered on the territory of Belarus.

\section{Results}

Order Strepsiptera Kirby, 1813

Family Stylopidae Kirby, 1813

Subfamily Stylopinae Kirby, 1813

Genus Hylecthrus Saunders, 1850

Hylecthrus rubi Saunders, 1850 
Material examined: Belarus, Gomel area, Gomel district, floodplain meadow in the valley of the Iput River east of the Gomel city, 52 ${ }^{\circ} 5^{\prime} 07^{\prime \prime} \mathrm{N}, 31^{\circ} 03^{\prime} 37^{\prime \prime} \mathrm{E}, 120$ a.s.1., 21.07.2019 - 1 \% of Hylaeus (Hylaeus) communis Nylander, 1852 stylopized by 1 \% of H. rubi (between $\mathrm{V}$ and VI tergites in the middle).

Hosts. H. (H.) communis Nylander, 1852 [11,12], H. (H.) angustatus (Schenck, 1861), H. (H.) leptocephalus (Morawitz, 1871), H. (Dentigera) brevicornis Nylander, 1852, H. (Koptogaster) punctulatissimus Smith, 1842, H. (Spatulariella) hyalinatus Smith, 1842, H. (S.) punctatus (Brülle, 1832), H. (Paraprosopis) albonotatus (Walker, 1871), H. (P.) clypearis (Schenck, 1853), H. (P.) pictipes Nylander, 1852, H. (P.) sinuatus (Schenck, 1853), H. (Prosopis) gibbus Saunders, 1850, H. (Pr.) signatus (Panzer, 1798), H. (Pr.) variegatus (Fabricius, 1798) [12].

Genus Stylops Kirby, 1802

Stylops hammella Perkins, 1918 *

Material examined: Belarus, Gomel area, Gomel district, Chenki forestry, the clearing in the mixed forest between the horticultural partnership "Motor" and Chenki village, $52^{\circ} 19^{\prime} 59^{\prime \prime} \mathrm{N}, 30^{\circ} 57^{\prime} 55^{\prime \prime} \mathrm{E}, 127$ a.s.1., 06.05.2018 - 10' of Andrena (Notandrena) chrysosceles (Kirby, 1802) stylopized by 19 of $S$. hammella (between IV and V tergites on the left).

Hosts. A. (N.) chrysosceles (Kirby, 1802) [13], A. (N.) nitidiuscula Schenck, 1853 [14,15].

Stylops melittae Kirby, 1802

Material examined: Belarus, Gomel area, Gomel district, field near Znamya Truda village, on the side of a country road, 52 $22^{\prime} 46^{\prime \prime} \mathrm{N}, 31^{\circ} 08^{\prime} 27^{\prime \prime} \mathrm{E}, 130$ a.s.1., $12.04 .2020-1$ of Andrena (Melandrena) nitida (Müller, 1776) stylopized by 1 of of S. melittae; in the same place, on the inflorescences of Salix acutifolia Wild. on the edge of a swamp, 52 $22^{\prime} 34^{\prime \prime} \mathrm{N}$, $31^{\circ} 09^{\prime} 05^{\prime \prime E}, 127$ a.s.1., 12.04.2020 - 19 of $A$. (M.) nitida stylopized by 19 of S. melittae; in the same place, on the support of the power line, $52^{\circ} 23^{\prime} 00^{\prime \prime} \mathrm{N}, 31^{\circ} 09^{\prime} 20^{\prime \prime} \mathrm{E}, 129$ a.s.1., 11.04 .2021 - 11 of $A$. (M.) nitida stylopized by 15 o of $S$. melittae; in the same place, $52^{\circ} 22^{\prime} 57^{\prime \prime} \mathrm{N}$, $31^{\circ} 09^{\prime} 01^{\prime} \mathrm{E}, 130$ a.s.1., 18.04.2021 - 29 of $A$. (M.) nitida stylopized by 4 우 of S. melittae.

Information about the nature of their stylization is presented in Table 1.

Table 1. The character of stylopization of the studied specimens of A. nitida by the strepsipteron $S$. melittae from the population of the Znamya Truda village in the Gomel district of the Gomel area.

\begin{tabular}{|c|c|c|}
\hline $\begin{array}{l}\text { Sex of the } \\
\text { Host Bee }\end{array}$ & $\begin{array}{l}\text { Number of } \\
\text { Parasites }\end{array}$ & $\begin{array}{c}\text { Their Localization between the Abdominal Segments } \\
\text { of the Host Bee }\end{array}$ \\
\hline q & 1 & $q$ between IV and V tergites on the left \\
\hline q & 1 & o between IV and V tergites on the right \\
\hline q & 2 & 29 between IV and V tergites on the sides \\
\hline q & 1 & $\%$ between IV and V tergites on the left \\
\hline q & 1 & \% between IV and V tergites on the right \\
\hline 운 & 1 & $q$ between IV and V tergites on the left \\
\hline q & 1 & o between IV and V tergites on the left \\
\hline q & 1 & $\$$ between IV and V tergites on the left \\
\hline q & 3 & $\begin{array}{l}\% \text { between IV and V tergites in the middle, } \\
2 \% \text { between IV and V tergites on the sides }\end{array}$ \\
\hline$q$ & 2 & $\begin{array}{l}\text { \% between III and IV tergites in the middle, } \\
\text { \% between IV and V tergites on the left }\end{array}$ \\
\hline 운 & 1 & o between IV and V tergites in the middle \\
\hline q & 1 & $q$ between IV and V tergites on the left \\
\hline 운 & 1 & $\%$ between IV and V tergites on the left \\
\hline$q$ & 2 & 29 between IV and V tergites on the sides \\
\hline q & 2 & $2 \%$ between IV and V tergites on the sides \\
\hline
\end{tabular}

Hosts. A. (M.) nigroaenea (Kirby, 1802) [16], A. (M.) nitida (Müller, 1776) [17], A. (Zonandrena) flavipes Panzer, 1799 [18], A. (M.) thoracica (Fabricius, 1775), A. (Z.) soror 
Dours, 1872 [14], A. (Z.) gravida (Imhoff, 1832) [19], A. (Hoplandrena) carantonica Pérez, 1902, A. (H.) ferox Smith, 1847 [20].

\section{Stylops thwaitesi Perkins, 1918 *}

Material examined: Belarus, Gomel area, Gomel district, floodplain meadow in the valley of the Uza River near Uza village, 52 ${ }^{\circ} 22^{\prime} 53^{\prime \prime} \mathrm{N}, 30^{\circ} 52^{\prime} 35^{\prime \prime} \mathrm{E}, 118$ a.s.l., 14.05 .2016 $10^{\pi}$ of Andrena (Taeniandrena) ovatula (Kirby, 1802) stylopized by 1 \% of $S$. thwaitesi (between IV and $\mathrm{V}$ tergites in the middle).

Hosts. A. (T.) ovatula (Kirby, 1802) [13,21], A. (T.) similis Smith, 1849 [22], A. (T.) albofasciata Thomson, 1870 [17,23], A. (T.) ezoensis Hirashima, 1965 [24,25], A. (T.) wilkella (Kirby, 1802) [14,17,23], A. (T.) intermedia Thomson, 1870, A. (T.) lathyri Alfken, 1899 [19].

Family Xenidae Saunders, 1872

Subfamily Paraxeninae Kinzelbach, 1971

Genus Paraxenos Saunders, 1872

Paraxenos sphecidarum (Dufour, 1837)

\section{Material examined:}

1. Belarus, Gomel area, Gomel district, Novobelitsa forestry, the clearing in the mixed forest south of the Gomel city, $52^{\circ} 19^{\prime} 48^{\prime \prime} \mathrm{N}, 31^{\circ} 00^{\prime} 15^{\prime \prime} \mathrm{E}, 123$ a.s.l., 6.06.2016 - $10^{\prime \prime}$ of $\mathrm{Am}$ mophila sabulosa (Linnaeus, 1758) stylopized by $10^{*}$ of $P$. sphecidarum (the remains of on puparium between IV and V tergites on the left).

2. Belarus, Gomel area, Gomel district, grassy slope on the edge of the sand quarry near Uza village, on the inflorescences of Solidago canadensis L., 52 $22^{\prime} 57 " \mathrm{~N}, 30^{\circ} 52^{\prime} 45^{\prime \prime} \mathrm{E}, 122$ a.s.l., 12.08.2017 - $10^{\text {r }}$ of $A$. sabulosa stylopized by 29 of P. sphecidarum (19 between IV and $\mathrm{V}$ tergites on the left and 19 between $\mathrm{V}$ and VI tergites in the middle).

3. Belarus, Gomel area, Bragin district, on a mixed-grass meadow bordering a pine forest near Kirovo village, $51^{\circ} 24^{\prime} 20^{\prime \prime} \mathrm{N}, 30^{\circ} 34^{\prime} 32^{\prime \prime} \mathrm{E}, 107$ a.s.l., $14.08 .2019-120^{\prime}$ and 89 of $A$. sabulosa stylopized by $17 \sigma^{\prime \prime}$ and $14 \%$ of $P$. sphecidarum.

Information about the nature of their stylization is presented in Table 2.

Table 2. The character of stylopization of the studied specimens of A. sabulosa by the strepsipteron $P$. sphecidarum from the population of the Kirovo village in the Bragin district of the Gomel area.

\begin{tabular}{|c|c|c|}
\hline $\begin{array}{l}\text { Sex of the } \\
\text { Host Wasp }\end{array}$ & $\begin{array}{l}\text { Number of } \\
\text { Parasites }\end{array}$ & $\begin{array}{l}\text { Their Localization between the Abdominal Segments } \\
\text { of the Host Wasp }\end{array}$ \\
\hline $0^{x}$ & 1 & The remains of $\sigma^{x}$ puparium between $\mathrm{V}$ and VI tergites on the right \\
\hline$\sigma^{x}$ & 2 & $\begin{array}{l}\text { The remains of } \sigma^{x} \text { puparium between IV and V tergites on the right, } \\
\text { क between VI and VII tergites on the left }\end{array}$ \\
\hline$\sigma^{x}$ & 1 & $o^{x}$ puparium between IV and V sternites in the middle \\
\hline q & 1 & $\sigma^{\pi}$ puparium between IV and V tergites on the left \\
\hline q & 2 & $\begin{array}{l}\text { } \text { between V and VI tergites on the right, } \\
\text { o between III and IV sternites in the middle }\end{array}$ \\
\hline q & 1 & The remains of $\sigma^{\prime}$ puparium between IV and $\mathrm{V}$ tergites on the right \\
\hline 운 & 1 & क between IV and V tergites on the left \\
\hline$\sigma^{\prime \prime}$ & 1 & $\sigma^{\top}$ puparium between V and VI sternites on the left \\
\hline$\sigma^{x}$ & 1 & The remains of $o^{\pi}$ puparium between IV and V tergites on the left \\
\hline$\sigma^{x}$ & 1 & The remains of $\sigma^{x}$ puparium between IV and V tergites on the left \\
\hline $0^{\pi}$ & 1 & $q$ between IV and V tergites on the right \\
\hline q & 4 & $\begin{array}{l}\text { \% between III and IV tergites on the right, } \\
\text { \% between IV and V sternites on the left, } \\
2 \% \text { between V and VI tergites on the sides }\end{array}$ \\
\hline$\sigma^{\prime}$ & 2 & $\begin{array}{l}\text { The remains of } \sigma^{x} \text { puparium between V and VI tergites on the right, } \\
\text { o between IV and V tergites on the left }\end{array}$ \\
\hline q & 3 & $\begin{array}{l}\text { The remains of or puparium between III and IV tergites on the left, } \\
\qquad q \text { between IV and V tergites on the left, } \\
\text { क between V and VI tergites on the right }\end{array}$ \\
\hline $0^{x}$ & 1 & The remains of $\sigma^{x}$ puparium between IV and $\mathrm{V}$ tergites on the right \\
\hline
\end{tabular}




\begin{tabular}{|c|c|c|}
\hline$\sigma^{\pi}$ & 2 & The remains of $2 \sigma^{n}$ pupariums between IV and V tergites on the sides \\
\hline$\sigma^{\pi}$ & 1 & The remains of ơ puparium between IV and V tergites on the right \\
\hline q & 3 & $\begin{array}{l}\text { The remains of ơ puparium between IV and V tergites on the left, } \\
\text { क between V and VI tergites on the right, } \\
\sigma^{\pi} \text { puparium between VI tergite and VI sternite above the sting }\end{array}$ \\
\hline q & 1 & The remains of $o^{\pi}$ puparium between V and VI tergites on the left \\
\hline $0^{\pi}$ & 1 & $q$ between V and VI tergites in the middle \\
\hline
\end{tabular}

4. Belarus, Gomel area, Bragin district, pine forest on the dunes with adjacent farmland and a dense network of reclamation channels between Asarevichi and Grushnoe villages, on dry meadow-steppe areas of a sandy slope with low grass vegetation, $51^{\circ} 37^{\prime} 22^{\prime \prime} \mathrm{N}, 30^{\circ} 25^{\prime} 52^{\prime \prime} \mathrm{E}, 106$ a.s.1., 18.08.2019 - 19 of $A$. sabulosa stylopized by $10^{\prime \prime}$ of $P$. sphecidarum (o' puparium between IV and V tergites on the right) and 1 o of $A$. sabulosa stylopized by $10^{\star}$ and 19 of $P$. sphecidarum (the remains of $\sigma^{\star}$ puparium between IV and V sternites on the right and $q$ between IV and V tergites on the right).

5. Belarus, Gomel area, Gomel district, sandy road along the mixed forest between the horticultural partnership "Glushets" and Mikhal'ki village, on the side of a country road, 52 $16^{\prime} 05^{\prime \prime} \mathrm{N}, 30^{\circ} 49^{\prime} 04^{\prime \prime E}, 118$ a.s.1., 08.09.2019 - 1 \% of Podalonia affinis (W. Kirby, 1798) stylopized by 19 of $P$. sphecidarum (between IV and V tergites on the right).

6. Belarus, Gomel area, Loev district, Karpovka village, on the side of a country road, $52^{\circ} 01^{\prime} 15^{\prime \prime} \mathrm{N}, 30^{\circ} 54^{\prime} 07^{\prime \prime E}, 115$ a.s.l., 12.06.2021 - 1\% of P. affinis stylopized by $10^{\prime \prime}$ and 19 of $P$. sphecidarum ( $\sigma^{\circ}$ puparium between IV and V tergites on the left and $\$$ between V and VI tergites on the right).

Hosts. A. sabulosa (Linnaeus, 1758) [10,20], A. pubescens Curtis, 1836 [26], P. affinis (W. Kirby, 1798) [27].

\section{Discussion}

It is quite obvious that the taxonomy of Strepsiptera is far from resolved. In genus Stylops additional name-changes are expected. In order to resolve the exact species delimitations molecular analyses are needed. Apart from the taxonomical uncertainties there are also a species of twisted-wing insects that are still expected to turn up in the Belarus because their hosts do occur here and are sometimes even quite common.

\section{Conclusions}

Thus, as a result of the studies carried out on the territory of the southeast of Belarus, five species of twisted-wing insects were identified, among which Stylops hammella Perkins, 1918 and S. thwaitesi Perkins, 1918 are new to the strepsipterofauna of the Republic.

Since the material identified is small, and there is no published data on the fauna of twisted-wing insects in Belarus and neighboring countries, this study can be considered to be only a preliminary overview. Further study is planned for the future, and an expansion of the species list of twisted-wing insects in Belarus is to be expected.

Funding: This research received no external funding.

Institutional Review Board Statement: The article does not contain any studies involving animals in experiments performed by the author.

Conflicts of Interest: The author states that he has no conflict of interest. 


\section{References}

1. Kinzelbach, R.K. Morphologische Befunde an Fächerflüglern und ihre phylogenetische Bedeutung (Insecta: Strepsiptera). Zoologica 1971, 119, 1-256.

2. Kathirithamby, J. Review of the Order Strepsiptera. Systematic Entomology 1989, 14, 41-92.

3. Kathirithamby, J. Host-Parasitoid Associations in Strepsiptera. Annual Review of Entomology 2009, 54, $227-249$.

4. Kathirithamby, J. Strepsiptera. Twisted-wing parasites. Version 24 September 2002 (under construction). The Tree of LifeWeb Project. Available online: http://tolweb.org/Strepsiptera/8222/2002.09.24 (accessed on 15 June 2021).

5. Kinzelbach, R.K.; Pohl, H. Ordnung Strepsiptera, Fächerflüger. Wirbellose Tiere. 5. Teil: Insecta; Spektrum Akademischer Verlag: Heidelberg-Berlin, Germany, 2003; ss. 526-539.

6. Pohl, H. Fauna Europaea: Strepsiptera. Fauna Europaea, ver. 2.4. Available online: http://www.faunaeur.org (accessed on 15 June 2021).

7. Soon, V.; Kesküla, T.; Kurina, O. Strepsiptera species in Estonia. Entomol. Fenn. 2011, 25, 213-218.

8. Medvedev, L.N. [The order Strepsiptera]. In Keys to the insects of the European part of the USSR. Coleoptera and Strepsiptera; BeyBienko, G.Ya., Eds.; Nauka Publ.: Moscow-Leningrad, USSR, 1965; Volume 2, Issue 89, pp. 641-645 (In Russian).

9. Ostrovsky, A.M. A first record of Stylops melittae Kirby, 1802 (Insecta: Strepsiptera: Stylopidae) in Belarus. Euroasian Entomol. J. 2018, 17(3), 189-190. DOI: 10.15298/euroasentj.17.3.08.

10. Ostrovsky, A.M. A new record of strepsipteron Paraxenos sphecidarum (Dufour, 1837), (Insecta, Strepsiptera: Xenidae) from Belarus. Euroasian Entomol. J. 2019, 18(3), 186-187. DOI: 10.15298/euroasentj.18.3.07.

11. Ostrovsky, A.M. Hylecthrus rubi Saunders, 1850 - a new species of strepsipteron (Insecta: Strepsiptera: Stylopidae) in the fauna of Belarus. Euroasian Entomol. J. 2019, 18(6), 412-413. DOI: 10.15298/euroasentj.18.6.9.

12. Kinzelbach, R.K. Redeskription und revision der Strepsipteren-Gattung Hylecthrus Saunders, 1850. Angew. Parasitol. 1971, 12(4), 204-219.

13. Perkins, R.C.L. Synopsis of British Strepsiptera of the genera Stylops and Halictoxenus. Entomologist's Monthly Magazine 1918, 54, 67-76, plate 1.

14. Luna de Carvalho, E. Contribuição para o estudo dos Stylops da Peninsula Iberica (Streps. Stylopidae). Eos: Revista Española de Entomologia 1974, 48, 301-365.

15. Poluszyński, G. Stylops nitidiusculae n. sp. Polskie Pismo Entomologiczne 1927, 6, 92-99.

16. Kirby, W. Monographia Apum Angliae; or, an attempt to divide into their natural genera and families, such species of the Linnean genus Apis as have been discovered in England: with descriptions and observations. In To which are prefixed some introductory remarks upon the class Hymenoptera, and a synoptical table of the nomenclature of the external parts of these Insects; Raw, J., Eds.; Ipswich: London, England, 1802; pp. 258.

17. Pasteels, J. Enquêtes sur les Strepsiptères (4e série). - Strepsiptères du Musée zoologique de Lausanne. Bulletin et Annales de la Société Entomologique de Belgique 1954, 90, 349-355.

18. Hofeneder, K. Stylops in copula. Verhandlungen der Zoologisch-Botanischen Gesellschaft in Wien 1924, 73, $128-134$.

19. Smit, J.T.; Smit, J.; Raemakers, I.P.; Hoorn, B. The Strepsiptera of the Netherlands revisited (Insecta). Entomologische Berichten 2020, 80(1), 8-30.

20. Klaus, M. Über Fächerflügler (Strepsiptera) bei Hautflüglern (Hymenoptera) in Franken und darüber hinaus. Galathea 2016, 32, 83-99.

21. Kifune, T.; Tadauchi, O.; Lee, C.E. Records of the Strepsiptera parasitic on the Korean Apoidea (Notulae StrepsipterologicaeXXIII). Esakia 1994, 34, 209-214.

22. Hofeneder, K. Über zwei neue Strepsipteren aus Andrena similis F. Smith und Halictus malachurus Kirby. Veröffentlichungen aus dem Deutschen Kolonial- und Übersee-Museum in Bremen 1939, 2, 181-200.

23. Günther, V.; Šedivý, J. Řád Řasnokřídlí - Strepsiptera. In Klíč zviřeny ČSR [Key to the fauna of Czechoslovakia]; Kratochvíl, J., Eds.; Čsav: Praha, Czechoslovakia, 1957; Díl II, pp. 407-417.

24. Kifune, T.; Hirashima, Y. Nine new species of the genus Stylops (Strepsiptera: Stylopidae) parasitic on the genus Andrena (Hymenoptera: Andrenidae) of Japan (Studies on the Japanese Strepsiptera X). Esakia 1985, 23, 45-57.

25. Kifune, T.; Maeta, Y. Ten new species of the genus Stylops (Strepsiptera, Stylopidae) parasitic on the genus Andrena (Hymenoptera, Andrenidae) of Japan (Studies on the Japanese Strepsiptera XIII). Esakia 1990, 29, 97-110.

26. Pekkarinen, A.; Raatikainen, M. The Strepsiptera of Eastern Fennoscandia. Notulae Enlomologicae 1973, 53, 1-10.

27. Ostrovsky, A.M. Podalonia affinis (W. Kirby, 1798) (Hymenoptera: Apoidea: Sphecidae), a new host species of the strepsipteran Paraxenos sphecidarum (Dufour, 1837) in Belarus. Euroasian entomological journal 2021, 20(1), 55-56. DOI: 10.15298/euroasentj.20.1.9. 